UDC 622

DOI: https://doi.org/10.26642/tn-2018-1(81)-303-308

\author{
V.O. Shlapak, PhD \\ I.V. Klimenko, the $2^{\text {nd }}$ year student, \\ I.V. Davydova, Ph.D. \\ Zhytomyr State Technological University \\ O.S. Tarasyuk, engineer \\ National Technical University of Ukraine «Igor Sikorsky Kyiv Polytechnic Institute»
}

\title{
Prospects for using broken stone quarries waste
}

The analysis of the production of broken stone materials shows that the processing enterprises of this product have problems with the storage of waste product. The dumps of waste cover huge areas of land suitable for agriculture use. The accumulation of waste also affects the environment. Its accumulation occurs due to the imperfect technology of waste products recycling. Granite screenings is the waste of this production. The introduction of modern waste recycling technologies allows to get washed sand, which becomes a competitive product.

The paper analyzes the granulometric composition of different types of sand, compares granulometric composition of different types of sand and the directions of use of sand in various industries, also it highlights construction and road works. In general, the paper is dedicated to the production of granite sand. The physical and mechanical properties of granite sand and its fractional composition are described. A comparison of the granulometric composition of granite sand with an «ideal» granulometric curve of filler with a grain size of $2.5 \mathrm{~mm}$ (by Fuller) is made. The analysis shows that the curve for washed sand closely approximates to the «ideal» curve. This fact indicates that granite sand has a wide range of applications as filler for production plaster and building mortars. According to quality indicators, washed sand meets European quality standards. The widespread use of granite screenings makes it possible to reduce the environmental impact and improve the technical and economic performance of enterprises that are engaged in mining of broken stone.

Keywords: granite screenings; granite waste; broken stone quarries; washed sand.

Introduction. Natural stone is the most common resource used for the production of building materials. Today, both in Ukraine and in other countries, there is a problem of the release of large areas of agricultural land from granite refuse which is accumulated in dumps, outside the enterprises.

Granite is one of the most common among the igneous rocks used in construction. Granite is an acidic rock composed of quartz (20-40\%), potassium feldspar - orthoclase (40-70\%) and muskid mica, or more often biotite (5-20\%). Due to high orthoclase content, the color of the granite is mostly gray, bluish gray, dark red. Granite has a granular-crystalline structure, 2600 to $2700 \mathrm{~kg} / \mathrm{m}^{3}$ density, a compressive strength limit of 100 to $250 \mathrm{MPa}$ and above. Granite, which is contained more of quartz and less of mica, has better construction properties.

Production of large fractions of broken stone forms a screenings in the amount of up to 20-25\% of the raw material. Production of cube-shaped broken stone of small fractions $(5-15 \mathrm{~mm})$ increases the amount of granite screenings to $40 \%$. In general, granite screenings has a certain commercial value and this product is partly sold by enterprises to local consumers. At the same time, the full sale of granite screenings is limited by the high content of dust particles. Typical granite screenings at Ukrainian quarries contains up to $30 \%$ of particles of less than $140 \mu \mathrm{m}$ in size, which have high water absorption and, therefore, do not allow the use of granite screenings in pure form for the manufacture of concrete.

The purpose of the work is to analyze and study the features of the use of granite screenings in the production of concrete, silicate products and other products. To analyze the advantages and disadvantages of granite screenings, river sand and ravine sand as filler, also the aim is to analyze the influence of the extraction processes of these materials on the environment.

Analysis of recent research and publications. One of the most promising directions of waste utilization is its use in the production of various reinforced concrete structures [1,2]. However, taking into account the cost of delivery, waste utilization is possible only at a short distance to the consumer. The use of screenings for the production of asphalt concrete mixtures with a fine granular material content up to $50 \%$ inclusive would significantly reduce the volume of accumulated waste [3,4]. At the same time, increasing the concentration of screenings in the mixture leads to an increase in bitumen and rising costs of asphalt concrete. In addition, for finegrained asphaltic concrete, a decrease in the strength limits is observed with the increase in the mineral content of screenings. It requires the introduction of fibrous polymer additives to a mixture [5]. At the same time, small volumes of carrying out of road works, connected with the difficult economic situation in the state, do not allow to effectively utilize the waste generated by broken stone. Granite screenings can also be used as sintering intensifiers under high-

(C) V.O. Shlapak, I.V. Klimenko, I.V. Davydova, O.S. Tarasyuk, 2018 
speed modes of burning up of floor tiles and for brick production in exchange for chamotte and sand [6], for the production of ceramic products [7], component for roofing materials, filters for water treatment plants [8, 9]. In addition to the above-mentioned directions, the ways of disposal of waste are its use as a decoration, for the lining of tracks, sports and playgrounds. Granite screenings also can be successfully applied to create a landscape. It is planned to use it as a means to fight with slippery road for reducing the slip factor [10].

Presentation of the main research material. Granulated sand is a proven alternative to river and lingering sand. It is produced by crushing rocks and by washing equipment and is divided into different fractions. It is used in the manufacture of concrete, mortar, plaster, borders, sidewalk tiles and other curly elements of paving. Besides a better granulometric composition and a larger of size module (Mk), crushed sand does not contain sludge, clay and organic admixtures. Granulometric composition of which is presented in Figure 1

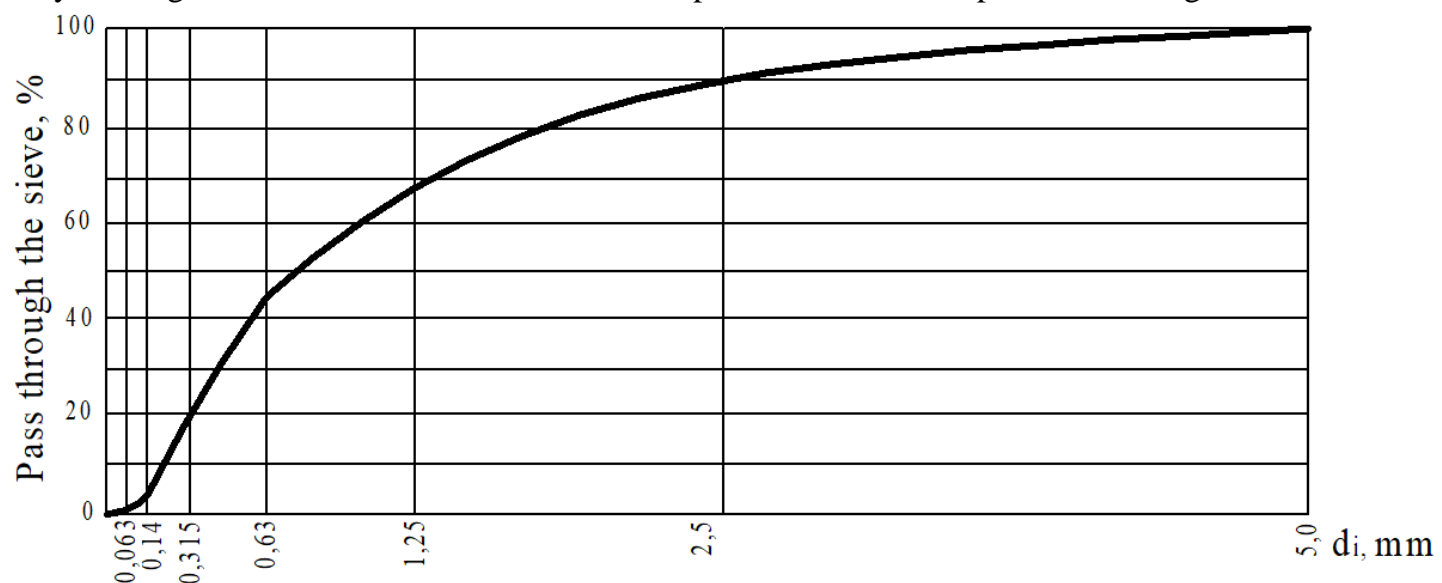

Fig. 1. Granulometric composition of granite sand

Historically, the screenings was a by-product of the crushing-sorting process. Due to its layered form of particles and flakiness, high dust content of its application as a fine aggregate in most concrete was impossible. The consumption of water and in the future and the consumption of cement were very high to achieve the specified characteristics of concrete and cement mortar. These reasons forced the concrete manufacturers to avoid the use of screenings as filler.

Ravine sand is natural sand, which is extracted using a variety of special equipment (excavators, bulldozers, earthmoving machines). The quality of the ravine sand is much lower than the river sand, and the admixtures of dust, clay, large stone fractions and other natural materials make it dirty, which, accordingly, reduce the price of ravine sand. Ravine sand granules have a rough surface and sharp edges, and on average they have a size of 1.6-2.0 mm. Ravine sand also has larger fractions, but it occurs less often. Granulometric composition is presented in Figure 2.

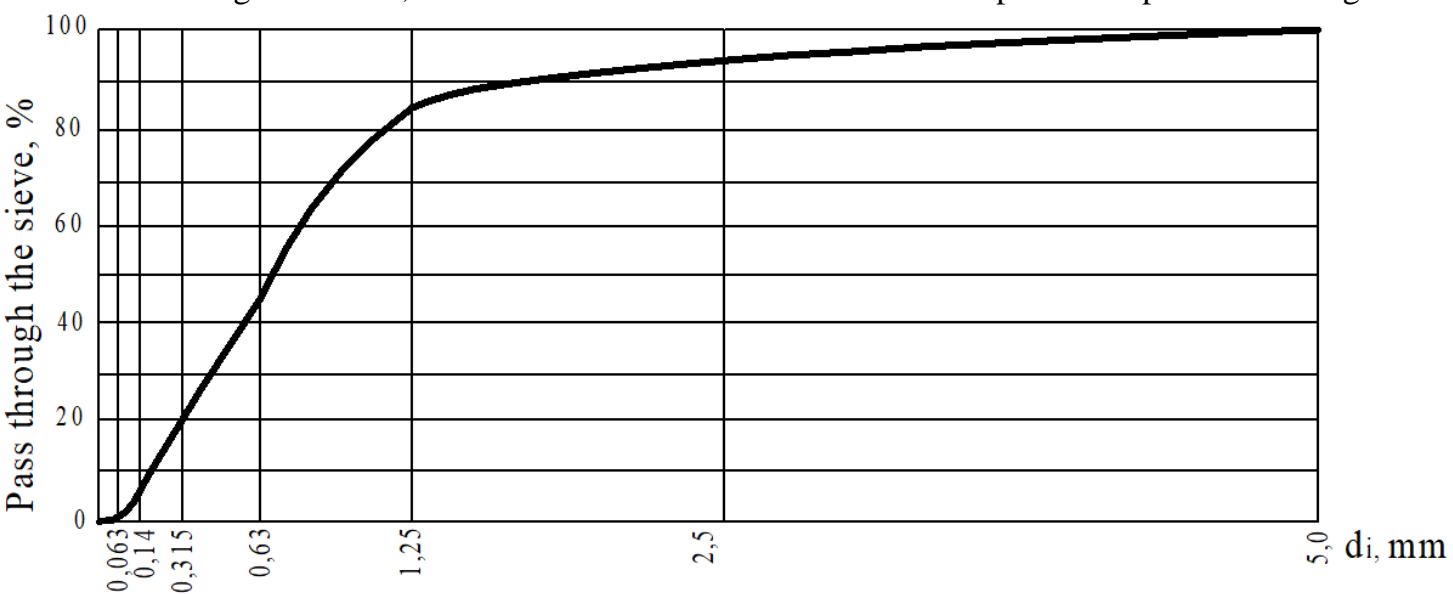

Fig. 2. Granulometric composition of ravine sand

Ravine sand is divided into three types:

- washed, it is extracted using dredges, i.e. it is washed in large quantities of water. The quality of this sand is getting closer to the river. Grain is identical of $0.6 \mathrm{~mm}$;

- $\quad$ sieved, it is extracted, and then sifted using special equipment, which makes it more qualitative. It is used for preparation of cement mortar and plaster mortar;

- ordinary, it is extracted in an open way. It has not high technical specifications as it includes a variety of admixtures. 
The river sand differs from the ravine sand in a higher price. As a rule, river sand is imported; it undergoes separation processes from gravel broken stone (pebbles). By the composition, the river sand is cleaner, and unlike the ravine sand contains no admixture of clay. However, there is a significant drawback in the river sand, it is very small, resulting in the production of concrete increases the consumption of cement. Granulometric composition of the river sand is presented in Figure 3.

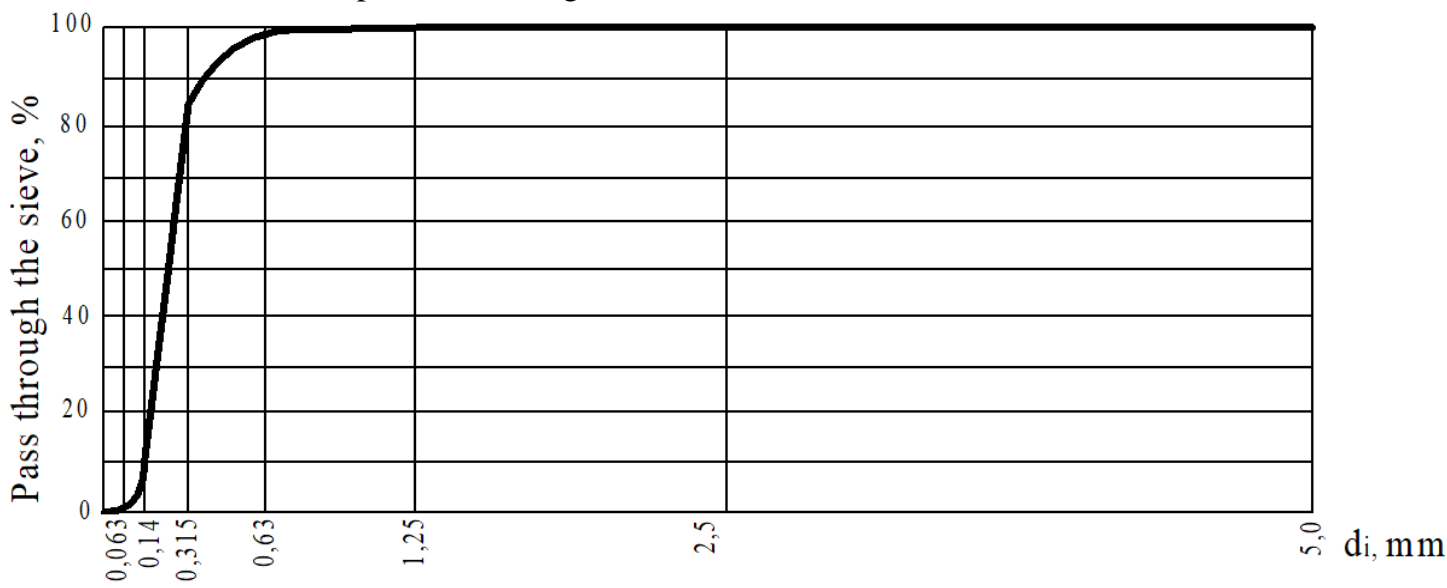

Fig. 3. Granulometric composition of river sand

Indicators of the granulometric composition of the river sand, washed granite sand and ravine sand are summarized in Table 1. It is clear from the table that the river and ravine sand is very small, but the granulometric curve of washed sand is as close as possible to the «ideal» curve of granulometric composition of the filler with a grain size limit of 2,5 mm (by Fuller), shown in Figure 4. This meets the requirements for the production of building materials, including concrete, building mortar and so on.

Comparative table of granulometric composition of river, granite washed and ravine sand

\begin{tabular}{|c|c|c|c|}
\hline Sieve, $\mathrm{mm}$ & River sand, pass \% & Granite washed sand, pass $\%$ & Ravine sand, pass \% \\
\hline $5 \mathrm{~mm}$ & 100 & 100 & 100 \\
\hline $2,5 \mathrm{~mm}$ & 100 & 90 & 94 \\
\hline $1,25 \mathrm{~mm}$ & 100 & 68 & 85 \\
\hline $630 \mu \mathrm{m}$ & 99 & 44 & 45 \\
\hline $315 \mu \mathrm{m}$ & 84 & 20 & 21 \\
\hline $140 \mu \mathrm{m}$ & 11 & 3 & 6 \\
\hline $63 \mu \mathrm{m}$ & 1 & 1 & 1 \\
\hline & $\mathrm{M}_{\mathrm{k}}=1,06$ & $\mathrm{M}_{\mathrm{k}}=2,75$ & $\mathrm{M}_{\mathrm{k}}=1.07$ \\
\hline
\end{tabular}

Granulated granite sand must have some qualitative parameters. Sector standards for small fillers, such as European EN 206-1 [11] or Ukrainian DSTU B V.2.7-210:2010 [12], allow only a limited amount of dust particles $(0.063-0.112 \mathrm{~mm})$ in wet sand. For high-quality concrete, the aggregate must contain less than $1 \%$ of dusty, muddy and clay particles to use as little cement and water as possible. Thus, pure granite sand with an «ideal granulometric curve» can be produced by washing. This allows making high-quality concrete and concrete products.

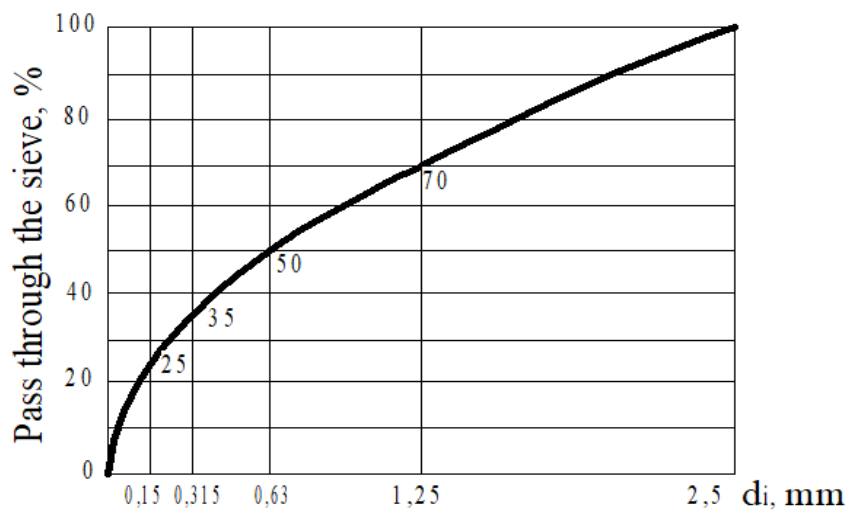

Fig. 4. «Ideal» curve of the granulometric composition of the filler with a grain size limit of $2.5 \mathrm{~mm}$ (by Fuller) 
Therefore, in recent years, concrete producers, together with producers of crushed stone, have begun to look for alternative solutions to reduce the consumption of cement, with the preservation of a given concrete brand. So, since 1999, the group of companies «Unigran» has started making fractions 0.63-2 and 2-5 mm. Fractions $0.63-2 \mathrm{~mm}$ are successfully used by manufacturers of roofing materials, in particular for the manufacture of finishing materials, flexible and hard tile, roofing material, tiles, and a fraction of 2-5 mm, concrete producers, mixing it with river sand, are used to increase the module of size $\left(\mathrm{M}_{\mathrm{k}}\right)$

The next step was the production of fine sand $0.16-0.63 \mathrm{~mm}$. Thus, due to a wide selection of small fillers of $0.16-0.63,0.63-2$ and $2-5 \mathrm{~mm}$, manufacturers of concrete, building mortars and sidewalk tiles are able to choose the ideal granulometric composition for the production of products by mixing these fractions in a certain proportion. Such sand has fewer voids, which makes it more economically profitable raw material, due to the reduction of the amount of cement in the mixture.

For making a mortar without sand, the ratio of cement and screenings in concrete should be as follows: cement brand 400-1 part, filler (best to apply granite screenings) -8 parts, water is also needed, which should not be more than $20 \%$ of the total volume. The ratio is aimed at getting concrete M150. If the builder realizes that the strength of such mortar is too small, he should use quality cement

If the concrete producers confuse the complete lack of sand, they can replace it in part. This requires the addition of broken stone. Consequently, if concrete is prepared from screenings, sand and cement, the proportions will be as follows: cement brand 400-1 part, screenings $-1-2$ parts, broken stone -3 parts, sand -3 parts, water - maximum $20 \%$.

At the same time, the ratio of screenings and other components almost does not affect the increase in the volume of the mixture, since the granules fill the gaps between the crushed stone, and also is a link between broken stone and sand.

Also, it should be noted that for the manufacture of high-quality concrete only cement with no expiration date should be used, in addition the material should be free from admixtures. Water for the preparation of concrete should be clean (it is better to use drinking water).

Given the popularity of this filler in the manufacture of concrete mix, one can come to the conclusion that the use of broken rock is a perfect solution. The debris is very popular in the construction sector due to its undeniable advantages. The material is profitable from a financial point of view; in addition, it allows you to make durable and long-lasting concrete. However, it should be born in mind that all the benefits of dropping are lost if the wrong solution is taken into account when creating the solution. Today, the manufacturers of building materials, due to the wide range of small fillers, have the opportunity to choose such granulometric curve, which is ideal for the production of high-quality concrete, building solutions, curbs, sidewalk tiles and other curtain elements paving $[15,16,17]$.

Granite screenings is popular as a material for road works and landscaping areas. In winter, it is used to spray the road surface (DSTU B V.2.7-210:2010) [11, 13]. Anti-slipping effect of granite sand is very high. The optimum size and density of the granite sand, as well as its structure, allow getting a rigid non-slip structure. It does not weather roads and lanes, which is very important for road safety and for public places in icy period. However, reducing the slip factor is not the only advantage of this material. It does not contain chemical reagents in its composition; therefore, it is safe for the environment. In addition, in some countries of the world where it is used, the remains are collected and used the next winter. Such an application is quite cost effective.

It is also important that the use of crushed granite sand instead of the river sand will solve a number of environmental problems, because uncontrolled extraction of river sand is the result of erosion of the river bed and the reduction of groundwater filtration. Also, the use of screenings leads to a decrease in the area occupied by the waste of crushed stone production. Gradual and systematic use of screenings in all directions of industry, construction and human activity will reduce the negative impact on the environment $[18,19]$.

Conclusions. Granite screenings of specified granulometric composition without extra admixtures in it, according to State Standard DSTU B V.2.7-210:2010 [11, 13], is used as a filler in concrete and building mortars. This increases the physical and mechanical performance and quality. It is applied in conducting road construction works, manufacturing a wide range of construction products, as well as in landscape construction, and other branch of industries. In accordance with EN 206-1 [12], the raw material described above meets the requirements of European standards and can be used both for export and for the manufacture of export products.

Prospects of further research. The granite screenings is characterized by a composition and property variety and a wide range of applications, therefore, the next stage of research is the study of properties of fillers one of the components of which is the waste of broken stone enterprises.

\section{References:}

1. Використання відсівів гранітного щебеню для виробництва товарного бетону / O.І. Іваненко, К.О. Кравченко, M.M. Вірник, А.І. Титюк // Восточно-Европейский журнал передовых технологий. - 2012. - Т. 2, № 12 (56). C. 16-18 [Электронный ресурс]. - Режим доступа : http://journals.uran.ua/eejet/article/view/3923/3591. 
2. Дворкін О.Л. Гранітні відсіви - заповнювач для вібропресованого бетону : зб. наук. пр. / О.Л. Дворкін, В.В. Житковський, Г.В. Доманський // Ресурсоекономні матеріали, конструкції будівлі та споруди. - 1999. Вип. 2.- С. 19-24.

3. Дорожно-строительные материалы / М.И. Волков, И.М. Борщ, И.М. Грушко, И.В. Королев. - Москва : Издво «Транспорт», 1975. - $527 \mathrm{c}$.

4. Якобсон М.Я. Бетон дорожный с использованием отсевов дробления изверженных горных пород для строительства автомобильных дорог : дисс. ... канд. техн. наук / М.Я. Якобсон. - Москва, 2000. - 258 с.

5. Властивості асфальтобетонів 3 волокнистою полімерною добавкою / В.К. Жданюк, О.О. Воловик, Д.Ю. Костин, К.В. Жданюк, О.О. Макарчев // Научно-технический сборник «Коммунальное хозяйство городов». Серия : Архитектура и технические науки. - 2009. - Вып. 90. - С. 214-217.

6. Утилизация отходов производства гранитного щебня / Л.А. Вайсберг, К.Н. Горбунова, М.Э. Каи и др. / Сборник «Пути экономии топливно-энергетических и материальных ресурсов в производстве строительных материалов». - Санкт-Петербург, 1985.

7. Экономия минеральных ресурсов при производстве керамических изделий / Л.А. Вайсберг, К.Н. Горбунова, М.Э. Кач и др. / Сборник «Пути экономии топливно-энергетических и материальных ресурсов в производстве строительных материалов». - Санкт-Петербург, 1985.

8. Аликин А.B. Модифицирование и кондиционирование отходов гранитного щебня / А.В. Аликин // Записки горного института. - 2011. - Т. 189. - С. 274-276.

9. Гелета О. Український ринок щебеню з природного каменю / О.Гелета // Коштовне та декоративне каміння. - 2008. - № 3 (53). - С. 3-11.

10. Матеріали посипкові для зимового утримання вулично-дорожньої мережі. Технічні умови : ДСТУ Б В.2.7XXX:201X. - [проект, остаточна редакція] / Мінрегіон України, 2010. - 23 с.

11. Concrete and related products. Technical committee : CEN/TC 104 EN 206-1. Part 1 : Specification, performance, production and conformity is a European standard elaborated by the CEN/TC 104 EN 206-1 [Concrete]

12. Пісок із відсівів дроблення вивержених гірських порід для будівельних робіт. Технічні умови : ДСТУ Б В.2.7-210:2010 / Мінрегіон України, 2010. - 20 с.

13. European integration: treatment of stone processing enterprises waste in Ukraine / V.V. Korobiichuk, O.M. Sidorov, R.V. Sobolevskyi, V.O. Shlapak, A.O. Kryvorushko // Вісник Житомирського державного технологічного університету. Серія : Технічні науки. - 2017. - № 1 (79). - С. 182-190.

14. Shamrai V.I. Management of waste of stone processing in the framework of Euro integration of Ukraine / V.I. Shamrai, V.V. Korobiichuk, R.V. Sobolevskyi // Вісник Житомирського державного технологічного університету. Серія : Технічні науки. - 2017. - № 2 (80). - Т. 1. - С. 234-239.

15. Investigation of Leznikovskiy Granite by Ultrasonic Methods / I.Korobiichuk et al. // Archives of Mining Sciences. - 2018. - Vol. 63, No. 1. - Pp. 75-82.

16. Korobiichuk V. Study of Ultrasonic Characteristics of Ukraine Red Granites at Low Temperatures / V.Korobiichuk // International Conference on Systems, Control and Information Technologies 2016. - Springer, Cham. - 2016. Pp. 653-658.

17. Давидова I.B. дослідження зміни режиму та складу поверхневих і підземних вод Житомирської області в межах зони розробки родовищ корисних копалин відкритим способом / I.B. Давидова // Вісник ЖДТУ. Серія : Технічні науки. - 2006. - № 1 (36). - С. 126-129.

18. Давидова I.B. Оцінка еколого-гідрологічного впливу на довкілля вибухових робіт при розробці нерудних родовищ корисних копалин / М.Т. Бакка, І.В. Давидова // Вісник КДПУ. - 2006. - Вип. 6 (41), Ч. 1. - С. $88-92$.

\section{References:}

1. Ivanenko, O.I., Kravchenko, K.O., Virnyk, M.M. and Tytjuk, A.I. (2012), «Vykorystannja vidsiviv granitnogo shhebenju dlja vyrobnyctva tovarnogo betonu», Vostochno-Evropejskyj zhurnal peredovblh tehnologyj, Vol. 2, No. 12 (56), pp. 16-18 [On-line], available at: http://journals.uran.ua/eejet/article/view/3923/3591

2. Dvorkin, O.L., Zhytkovs'kyj, V.V. and Domans'kyj, G.V. (1999), «Granitni vidsivy - zapovnjuvach dlja vibropresovanogo betonu», zb. nauk. pr., Resursoekonomni materialy, konstrukcii' budivli ta sporudy, Vol. 2, pp. 19-24.

3. Volkov, M.I., Borshh, I.M., Grushko, I.M. and Korolev, I.V. (1975), Dorozhno-stroitel'nye materialy, Izd-vo «Transport», Moskva, $527 \mathrm{p}$.

4. Jakobson, M.Ja. (2000), Beton dorozhnyj s ispol'zovaniem otsevov droblenija izverzhennyh gornyh porod dlja stroitel'stva avtomobil'nyh dorog, Diss. of kand. tehn. nauk, Moskva, 258 p.

5. Zhdanjuk, V.K., Volovyk, O.O., Kostyn, D.Ju., Zhdanjuk, K.V. and Makarchev, O.O. (2009), «Vlastyvosti asfal'tobetoniv z voloknystoju polimernoju dobavkoju», Nauchno-tehnycheskyj sbornyk «Kommunal'noe hozjajstvo gorodov», Seryja Arhytektura y tehnycheskye nauky, Vol. 90, pp. 214-217.

6. Vajsberg, L.A., Gorbunova, K.N., Kac, M.Je. and others (1985), «Utilizacija othodov proizvodstva granitnogo shhebnja», Puti jekonomii toplivno-jenergeticheskih i material'nyh resursov v proizvodstve stroitel'nyh materialov, sbornik, «Sankt-Peterburg.

7. Vajsberg, L.A., Gorbunova, K.N., Kac, M.Je. and others (1985), «Jekonomija mineral'nyh resursov pri proizvodstve keramicheskih izdelij», Puti jekonomii toplivno-jenergeticheskih $i$ material'nyh resursov $v$ proizvodstve stroitel'nyh materialov, sbornik, Sankt-Peterburg.

8. Alikin, A.V. (2011), «Modificirovanie i kondicionirovanie othodov granitnogo shhebnja», Zapiski gornogo instituta, Vol. 189, pp. 274-276. 
9. Geleta, O. (2008), «Ukrai'ns'kyj rynok shhebenju z pryrodnogo kamenju», Koshtovne ta dekoratyvne kaminnja, No. 3 (53), pp. 3-11.

10. Minregion Ukrai'ny (2010), DSTU B V.2.7-HHH:201H: Materialy posypkovi dlja zymovogo utrymannja vulychnodorozhn'oi' merezhi. Tehnichni umovy [Predatory materials for winter maintenance of the street-road network. Specifications], proekt, ostatochna redakcija, Ukrai'na, 23 p.

11. European standard, CEN/TC 104 EN 206-1: Concrete and related products. Technical committee, Part 1 «Specification, performance, production and conformity is a European standard elaborated by the CEN/TC 104 EN 206-1», Concrete.

12. Minregion Ukrai'ny (2010), DSTU B V.2.7-210:2010: Pisok iz vidsiviv droblennja vyverzhenyh girs'kyh porid dlja budivel'nyh robit. Tehnichni umovy [Sand from the dumping of crushing of eruptive rocks for construction work. Specifications], Ukrai'na, $20 \mathrm{p}$.

13. Korobiichuk, V.V., Sidorov, O.M., Sobolevskyi, R.V., Shlapak, V.O. and Kryvorushko, A.O. (2017), «European integration: treatment of stone processing enterprises waste in Ukraine», Visnyk Zhytomyrs'kogo derzhavnogo tehnologichnogo universytetu, Serija Tehnichni nauky, No. 1 (79), pp. 182-190.

14. Shamrai, V.I., Korobiichuk, V.V. and Sobolevskyi, R.V. (2017), «Management of waste of stone processing in the framework of Euro integration of Ukraine», Visnyk Zhytomyrs'kogo derzhavnogo tehnologichnogo universytetu, Serija Tehnichni nauky, No. 2 (80), Vol. 1, pp. 234-239.

15. Korobiichuk, I. and others (2018), «Investigation of Leznikovskiy Granite by Ultrasonic Methods», Archives of Mining Sciences, Vol. 63, No. 1, pp. 75-82.

16. Korobiichuk, V. (2016), «Study of Ultrasonic Characteristics of Ukraine Red Granites at Low Temperatures», International Conference on Systems, Control and Information Technologies, Springer, Cham, pp. 653-658.

17. Davydova, I.V. (2006), «doslidzhennja zminy rezhymu ta skladu poverhnevyh i pidzemnyh vod Zhytomyrs'koi' oblasti v mezhah zony rozrobky rodovyshh korysnyh kopalyn vidkrytym sposobom», Visnyk ZhDTU, Serija Tehnichni nauky, No. 1 (36), pp. 126-129.

18. Bakka, M.T. and Davydova, I.V. (2006), «Ocinka ekologo-gidrologichnogo vplyvu na dovkillja vybuhovyh robit pry rozrobci nerudnyh rodovyshh korysnyh kopalyn», Visnyk KDPU, Vol. 6 (41), Part 1, pp. 88-92.

Shlapak Volodymyr Oleksandrovich - Ph.D., Associate Professor of Deposits Development Department named after M.T. Bakka, Zhytomyr State Technological University.

Scientific interests:

- mining;

- construction materials;

- computer technologies.

Klimenko Ivan Victorovich - the $2^{\text {st }}$ year student, Mining and Ecology Faculty, Deposits Development Department named after M.T. Bakka, Zhytomyr State Technological University.

Scientific interests:

- mining.

Davydova Iryna Volodymyrivna - Ph.D., Associate Professor of Ecology Department, Zhytomyr State Technological University.

Scientific interests:

- industrial ecology;

- radioecology;

- lanscape ecology.

Tarasyuk Olena Stepanivna - engineer, Geoengineering department, National Technical University of Ukraine «Igor Sikorsky Kyiv Polytechnic Institute». 